\title{
12 Reconstructing Aboriginal Economy and Society: The New South Wales South Coast at the Threshold of Colonisation
}

Ian Keen's 2004 monograph, Aboriginal Economy and Society: Australia at the Threshold of Colonisation, represents the first anthropological study to draw together comparative pre- and postcolonial data sets and sources to explain the nature and variety of Aboriginal economy and society across the Australian continent. Keen's (2004: 5) rationalisation for comparing the economy and society of seven regions was 'mainly descriptive and analytical', in order to 'shed light on the character of each region, and to bring out their similarities and differences'. In doing so, as Veth (2006: 68) commented in his review of the book, 'It speaks to meticulous and exhaustive research from myriad sources including social anthropology, linguistics, history, ecology and, not the least, archaeology'. Following its publication, Aboriginal Economy and Society: Australia at the Threshold of Colonisation won Keen his second Stanner Award from the Council of the Australian Institute of Aboriginal and Torres Strait Islander Studies in 2005.

In this chapter, I draw upon Keen's comparative method to profile the ecology, institutions and economy of the Yuin people of (what is now) the Eurobodalla region of the New South Wales south coast at the time of European colonisation. ${ }^{1}$

1 Elsewhere I have documented the role of Aboriginal workers in the New South Wales south coast horticultural sector in the mid-twentieth century (White 2010a, 2010b, 2011) and have detailed the reactions of Yuin people to colonial incursions, which involved the development of intercultural relations that were mediated by exchange (White 2012). 
The reasons for this are twofold. First, Keen's model breaks down the observable (or reconstructable) aspects of economy and society into relatively comparable categories to enable a profile to be built based on the available sources. Accordingly, I profile the Yuin under the interconnected themes of ecology, institutions and economy, drawing on a range of ethnographic, linguistic and archaeological material. Second, Keen refers to the Kŭnai of Gippsland, eastern Victoria, as occupying a broad resource zone in the southeast- a resource zone that is shared by the Yuin. In this chapter, I will draw some conclusions about whether the similar environments and resources utilised by both groups gave rise to similarities in the economy and society of the Kŭnai and Yuin. Evidence of substantial similarities between the two groups will support Keen's (2004: 3) assertion that ecology is integral to economy: 'Environments constitute arenas for human action and being, they yield resources to be exploited, and they impose constraints and provide enabling conditions for practices.'

\section{Why Compare?}

Arguably, Keen's comparative approach developed as a product of his dissatisfaction with both the relative disinterest by anthropologists and historians in documenting Aboriginal economies and participation in the settler economy, and previous attempts to present a range of Aboriginal beliefs and practices in some kind of systematic way. On the former, Keen (2010: 1) noted that historians have been particularly guilty in rendering Indigenous Australians 'more or less invisible in many economic histories of Australia', while anthropologists were mainly concerned with Aboriginal beliefs and practices until Rowley (1970, 1971) 'brought about a sea change in the recognition of Indigenous involvement in the colonial economy' (Keen 2010: 2). On the latter, Keen's (1993) scathing review of Swain's (1993) A Place for Strangers signposts the comparative and systematic research on Aboriginal economies, beliefs and practices that Keen published a decade later. On Swain's argument that some aspects of all Aboriginal precolonial cultures were the same across the continent, Keen proposes that it serves a useful purpose - to 'help one to imagine the intellectual climate in which functionalism, an empiricist methodology and an emphasis on long-term fieldwork were engendered in reaction to "conjectural history" and especially to the excesses of extreme diffusionism' (Keen 1993: 107).

Several authors have attempted to provide reconstructions of Aboriginal economies (Butlin 1993; Dingle 1988; Lawrence 1968). One of the main problems in these studies is that their analytical frames are often too general and miss the highly localised and idiosyncratic nature of Aboriginal economies and societies. Several other studies have documented community economies in articulation with capitalist modes of production and the state (Altman 1987; Anderson 
1984). These studies provide a more adequate comparative framework for reconstructions of Aboriginal economies, and contributed to the development of the categories used in by Keen in Aboriginal Economy and Society: Australia at the Threshold of Colonisation.

Keen sketches a 'possibilist' model of 'the relationship between environment and society, according to which the environment imposes limiting conditions or boundaries on human action and social relations rather than causing them' (Keen 2004: 21). Furthermore, relationships between human practices and environments and resources are viewed as 'mutual, interactive' ones (ibid.). Keen argues that ecological factors must be taken into account because the location and seasonality of resources greatly affected the organisation of production, for people had to move to the locations of food resources' (ibid.: 23). Technologies (defined as the material instruments Aboriginal people use and the knowledge of their appropriate use) were also tailored to locally specific needs that were shaped by ecological constraints. These ecological factors also placed constraining conditions or boundaries on 'the ways in which Aboriginal people moved around the country, the degree of mobility, the range of movement, the size and dynamics of residence groups' and population densities (ibid.: 103).

Keen takes the middle road between what Giddens refers to as institutions (the more 'enduring' aspects of social life which 'are deeply sedimented in space-time') and Bourdieu's (1977) notion of a 'social field' to provide a category for analysis he terms 'institutional fields' (Giddens 1979: 80; Keen 2004: 3). Keen acknowledges that 'the categories of institutional field' he uses (for example, 'cosmology') 'probably overlap only partially with Aboriginal ones' but that, 'nevertheless, similarities between ethnographic descriptions such as kin relations ... are sufficient to make the domains proposed here workable' (Keen 2004: 3-4). In examining the institutional fields across seven regions, Keen includes the categories of identities (including 'country groups', language varieties, marriage rules, totemic identities and naming systems), kinship and marriage, and cosmology, quasi-technology and ancestral law.

Keen's perspective on 'economy' borrows from Sahlins's (1974) substantivist approach and discussions of gift exchange by Mauss (1954), Gregory (1982), Weiner (1992) and Godelier (1999) to outline a range of categories for analysis under more general topics, including control of the means of production, organisation of production, distribution and consumption, and exchange and trade. 


\section{Overview of Sources}

Four main ethnographic sources provide key information for a reconstruction of Yuin economy and society when Europeans first reached southeastern Australian shores: George Augustus Robinson, Harry Warner, Alfred William Howitt and Robert Hamilton Mathews. Robinson was the Chief Protector of Aborigines for Port Phillip and travelled widely during his tenure. He travelled through the Monaro and parts of the south coast during 1844 and his field journals contain valuable information relating to customary journeys and intermarriage between Aboriginal people at Twofold Bay and far-east Gippsland. Robinson's journals illustrate that the majority of marriages occurred between people living within the broad south coast geographic region, although several marriages were with people from Gippsland and also the Monaro Plateau. Unfortunately Robinson never ventured north beyond the Bega River and therefore his journals provide little information relating to Yuin people living within what is now known as the Eurobodalla. By contrast, Harry Warner, the son of a wattle-bark buyer, travelled through the Eurobodalla region between 1916 and 1940 and recorded extensive information on the Brinja-Yuin. Although Warner's observations occurred long after European invasion and settlement, his undated notes provide useful information on the location of different countries and economic practices.

Both Howitt and Mathews conducted their research after more than five decades of European intrusion into the region. A.W. Howitt worked as a geologist, mining warden and magistrate during the 1870s, and as a result of his work (and interests in surveying and ethnography) also travelled broadly throughout eastern Victoria and southeastern NSW. Howitt's major work, The Native Tribes of South-East Australia, was published in 1904 and provides useful information relating to Yuin social organisation, identities, marriage networks and totemic classifications.

Mathews was also a surveyor who had served as a magistrate and coroner while pursuing his interests as an amateur linguist and ethnographer. However, Mathews and Howitt were two very different men with different preconceptions and predilections that produced very different insights. ${ }^{2}$ Through observations collected while he was working as government surveyor, Mathews wrote a number of journal articles and a large body of unpublished papers relating to his research, yet never produced a major work in the style of Howitt. ${ }^{3}$

\footnotetext{
2 For an examination of Howitt's work, see Keen (2000). For an examination of Mathews's contributions to anthropology, see Elkin (1975a, 1975b, 1976) and Thomas (2004, 2006, 2011).

3 Arnold Van Gennep wrote to Mathews from Paris in 1909, despairing that Mathews had not synthesised his material into a magnum opus in the manner of Howitt (1904) and Baldwin Spencer (1899).
} 
Sadly for the ethnographic record, Howitt and Mathews did not share information about the social organisation of the people whom they both studied. ${ }^{4}$ Rather, as Thomas observed, Howitt and Baldwin Spencer 'formed a compact between themselves that Mathews' numerous publications should never be cited or even acknowledged' (Thomas 2004: 2). Thomas (2011: 8) gives a number of reasons for Mathews' treatment by his contemporaries, the most compelling being Mathews' dismissal of 'the great shibboleths of evolutionism' to which Spencer ('a leviathan of the discipline') subscribed. Thomas (2004: 2) further notes that 'the usual policy (apparently also shared by Roth) was to treat Mathews as a non-person'.

While Howitt might be credited as the key ethnographer in the south coast region because of his 1904 monograph, his account of social organisation is contradictory and frustrating because of its lack of complexity. Howitt believed that the Yuin 'had only traces of a class organisation', with two vaguely defined intermarrying classes and exogamous patrilineal totems (Howitt 1904: 261). Mathews' understanding of Yuin social organisation is as difficult to ascertain today as it was for his European correspondent Arnold Van Gennep in 1907; however, many clues remain that present a far more complex perspective than Howitt's model. ${ }^{5}$

The linguistic record is similarly patchy, with the main sources of linguistic evidence of Yuin dialects being collected by Mathews during his period of research on the south coast (c. 1890-1900), by Robinson (c. 1844), by Larmer (c. 1853) and by McKenzie (c. 1872). Drawing on Mathews' work, their own original research and a range of other sources, Tindale (1974) and Eades (1976) mapped the distribution of south coast languages. As Wesson notes, Eades' study differed from Tindale's in that she made a distinction between language groups and 'named groups' (Wesson 2000: 155). ${ }^{6}$

The New South Wales south coast region encompasses a rich array of sites of archaeological significance. Accordingly, a large body of archaeological research has been conducted that offers time-depth to the early ethnographies (see, for example, Bowdler 1976; Flood 1982; Lampert 1971 and Poiner 1976). ${ }^{7}$ Attenbrow (1999) provides a detailed review of archaeological research in the

\footnotetext{
4 The only letters from Howitt in the R.H. Mathews collection were from Howitt to H.E. Hockey requesting information about Aboriginal people at Brewarrina (Howitt 1907a, 1907b). Presumably Hockey had handed the letters over to his good friend Mathews.

5 Elkin's (1975a, 1975b, 1976) examination of Mathews' legacy and extensive study of Mathews' papers provide a montage of observations and understandings about Aboriginal people in southeastern Australia.

6 Wesson has made a significant contribution to the understanding of Aboriginal history in southeastern Australia and both her historical atlas (2000) and thesis (2002) contain a wealth of information on the distribution of languages, named groups, place names, families and individuals in the nineteenth century. 7 Much of the body of archaeological research in the region relates to details of, and changes in, indigenous resource use and technologies.
} 
study region and argues that significant knowledge has been gained about changes over time through numerous excavations of coastal middens, rock shelter deposits and open camp sites. The overall picture is that, at the time of colonisation, Aboriginal people in the Eurobodalla were mainly fisher people who roamed inland when resources were scarce on the coast. Furthermore, coastal groupings were generally associated with drainage basins that had relatively narrow 'beach frontages' and stretched inland to the top of the escarpments. The archaeological record makes it clear that Aboriginal people experienced a long and dynamic precolonial history, and that Aboriginal economy and society were by no means static.

\section{Ecology}

Under the general heading of 'ecology', Keen surveys the environments, resources, technologies, population densities and patterns of settlement and mobility of each of the seven regions. For Keen (2004: 3), these 'ecological aspects' are 'integral to economy' because 'environments constitute arenas of human action and being, they yield resources to be exploited, and they impose constraints and provide enabling conditions for practices'. Following Keen, in this section I survey the ecological aspects of the Eurobodalla, which are broadly similar to those of the Kŭnai in Gippsland.

What is now referred to as the Eurobodalla Shire lies in southeastern NSW, to the east of the Great Dividing Range, between $35^{\circ} 40^{\prime}$ and $36^{\circ} 2^{\prime}$ south and $149^{\circ} 5^{\prime}$ and $150^{\circ} 2^{\prime}$ east. The region is bordered by the Pacific Ocean to the east and the escarpments rising to the Monaro Plateau to the west, and consists of three major drainage basins (from north to south) of the Clyde, Deua and Tuross River systems, and smaller drainages feeding the Wagonga Inlet and Wallaga Lake estuarine systems. The broad, shallow valleys are subject to flooding during times of heavy rainfall, and the worst flooding occurs when the river mouths have been closed by sand deposition. The escarpments rise gradually out of these drainage basins to the Monaro Plateau. The highest mountains in the escarpments are now known as Pidgeon House Mountain, Mount Dromedary/ Gulaga (956 metres above sea level), Mumbulla Mountain and Mount Imlay (from north to south). These mountains have been described as providing important 'spiritual reference points to Aboriginal people' (Wesson 2000: 129).

Yuin people lived, and continue to live, in an environment with a temperate climate and high rainfall, characterised by long, warm (and occasionally hot) summers and cool winters. The average annual rainfall for Moruya Heads is $953.7 \mathrm{~mm}$, with the heaviest rainfalls occurring in the summer months. While the Eurobodalla climate enjoys relatively high rainfall all year round, 
the winter months coincide with the lowest monthly averages. In comparison to nearby Braidwood (located on the Monaro Plateau at an elevation of 643 metres), the Eurobodalla coast is considerably wetter and the relative proximity to the ocean produces a far less variable range in seasonal temperatures. On the plateau, Braidwood's average annual rainfall is $718.2 \mathrm{~mm}$, and its climate is characterised by colder nights and considerably colder winters, with severe frosts common from June to September.

The Eurobodalla environment consists of diverse terrestrial ecosystems ranging from various kinds of dry eucalypt forests and rainforests in the escarpments, to grasslands, wetlands, coastal sand scrub, dune complexes and rocky outcrops. These ecosystems were (and are) home to a diverse range of edible species, including plants, mammals, reptiles, birds, fresh and saltwater fish, crustaceans and molluscs. The main river systems are fed by numerous small streams and, combined with relatively high annual rainfall and occasional flooding, produce an abundance of potable water.

The ethnographic and archaeological accounts provide little information on the contribution of plant foods to Yuin people's diets. The oral history record identifies a range of edible fruits, and it is likely that various edible roots, rhizomes, tubers and other plant food sources provided year-round staples or were used for medicinal and other practical purposes (Chittick and Fox 1997; Dale Donaldson 2006, 2008). A variety of terrestrial mammals (found mainly in the grasslands and eucalypt forests), reptiles and birds contributed to the diet of the Yuin (Dale Donaldson 2006: 163-6). The remaining sources of protein available to Yuin people were derived from the various freshwater, estuarine and marine ecological zones.

According to Howitt, the functional name 'Katungal Yuin' referred to a people whose lifestyle was oriented towards gaining subsistence from the sea. Howitt's observations are supported by archaeological and ethnographic evidence. For example, Lampert argues that the archaeological evidence supports the theory that there was an 'almost complete dependence by coastal groups on seafoods for the protein portion of their diet. Only a few items, mainly vegetable foods, were derived from the bush' (Lampert 1971: 118). Similarly Harry Warner (n.d.: 2) observed that the Yuin relied mainly on the gathering of shellfish and hunting small land fauna, while the gathering of supporting plant foods was a seasonal activity of minor importance.

However, Poiner asserts that coastal groups did not live exclusively in camps close to the coast. Through an examination of the availability of potential dietary contributions of fish, shellfish and plant categories, Poiner argued that the cold winter months yielded the least in coastal and estuarine food resources. Poiner suggests that these months of relative scarcity reduced community size 
and resulted in smaller, 'more nomadic' coastal groups roaming inland as part of the food quest (Pointer 1976: 193; cf. Lampert 1971: 121). Based on the freezing conditions in the escarpments and on the plateau during winter, I suggest that this inland movement would have been limited and mobility was relatively aseasonal for coastal groups.

With an orientation towards coastal and estuarine environs, coastal Yuin people utilised a range of technologies to catch fish or to collect shellfish. The most significant material instruments of this type prior to colonisation were fishing lines, hooks and spears, flat water canoes, and flat water and ocean-going rafts. Aboriginal people also utilised a range of tools, weapons and facilities (including fish traps). ${ }^{8}$ It is likely that Yuin people also used what Hotchin (1990) described as a general east-coast toolkit consisting of cloaks and rugs of possum skin, various types of fighting clubs, and hunting and fighting spears (Keen 2004: 96). Warner observed that, amongst the Brinja-Yuin of the northern Tuross Lakes area, certain movable technologies (spears, canoes and axes) were more or less 'owned' by the individuals who produced them, although they were shared (or 'loaned') for mutual economic benefit. Warner differentiated between 'movable' and 'real' property, and argued that the latter category (including wurleys, wurley bark slabs, windbreaks, freshwater storages, bark canoes, hearths and hearth-stones and support forks) were 'freely appropriated for use by other Aborigines' once the camp was vacated (Warner n.d.: 5).

The Eurobodalla region appears to have been an environment favourable to human habitation (in terms of high rainfall and a temperate climate) and of relative abundance in a wide variety of available food sources. It is therefore curious that contemporary estimates suggest a relatively small population of around a thousand people living between Twofold Bay and Narrawallee at the time of European settlement (1822-23) (Wesson 2000: 130). It is possible that Yuin people were affected by smallpox epidemics that spread southwards from the north of the continent prior to European colonisation (Butlin 1985; Campbell 2007). Regardless of the overall population size prior to colonisation (and the obvious problems associated with estimation), the evidence suggests that relatively large groups of people congregated when resources were plentiful along the coast during summer, and at larger gatherings including those associated with the beaching of whales and the Bogong moth feasts in the highlands (see Flood 1980; Mathews 1904: 252-3). During the months of relative scarcity (June-September), Keen's comparative material suggests that group size would have been lower, both on the coast and in the escarpments. 
A combination of the ethnographic, archaeological and oral history sources suggests that a number of smaller 'socio-territorial political ensembles' held areas of land and water in the Eurobodalla (Correy et al. 2008: 7-8). Yet the evidence also suggests that individuals within those groups had rights to use the country of several groups based on various kinds of connections. Rather than moving around in large numbers, these smaller socio-territorial political ensembles (or 'country groups') probably also consisted of smaller familial groups that moved from one residence group to another (Keen 2004: 107). ${ }^{9}$ In this manner, Yuin mobility appears similar to that of the Kŭnai where individuals and families travelling to the country of other groups could visit relatives and gain access to particular resources in particular seasons' (Keen 2004: 108).

\section{Institutions}

The categories of institutional fields that Keen uses for the seven regions include identities, kinship and marriage, cosmology and quasi-technology, and governance. This section examines the available sources according to these categories to argue that Yuin, as an identity, existed as an ensemble of smaller intermarrying 'country groups' that shared a similar orientation towards living in the coastal/escarpment environs, participated in shared ceremonial activities and spoke mutually intelligible languages.

Howitt observed that the Yuin 'tribes' claimed the country along the coast from the Shoalhaven River in the north to Cape Howe in the south, bounded by escarpments rising to the Monaro Plateau in the west. ${ }^{10}$ According to Howitt, the Yuin were constituted by two subdivisions: the Kurial in the north, and the Guyangal in the south (Howitt 1904: 81). ${ }^{11}$ Howitt described the local organisation in terms of these two 'sub-tribes', which were further divided into six smaller 'clans'. Besides the north/south differentiation of Yuin identities, Howitt thought that the Yuin were also divided by way of their proximity to the ocean, with Katungal used to describe people living on the coast, and Paiendra

\footnotetext{
9 It is important to make the distinction between landowning groups and residence groups. Following Keen, I use 'country groups' to refer to groups that "held" or "owned" one or more defined countries and the associated myths, ceremonies, and sacred objects' (Keen 2004: 421). For a detailed examination of the development of, and debate around, anthropological models of Aboriginal rights and interests to land and resources, see Hiatt (2006: 13-35).

10 Wesson notes that 'the term yuin/yoo-inj/uin/youeen has been translated as man although it may have meant both person and man' (Wesson 2000: 129).

11 According to Howitt, the names originated from the words guya, meaning 'south', and kuru, meaning 'north'. The word gal was the possessive postfix (ibid.).
} 
for people living further inland (Howitt 1904: 82). ${ }^{12}$ Wesson (2000) describes these east/west differentiations as 'functional names' that were influenced by the distinctive ecological zones associated with the livelihoods of the respective groups (Wesson 2000: 151).

More recent work by Tindale (1974) similarly differentiated between Yuin people living on the coast as opposed to those living in the escarpments and on the plateau, and divided the north/south territory of the Katungal Yuin into smaller territorial units including (from Burrill Lake in the north to the Wallaga Lake region in the south) the Wandandian, Walbanga and Djiringanj. While conducting research on the south coast at roughly the same time, it is implicit that Warner thought that the territory of the Walbanga subgroup was further divided into different country groups including that of the Brinja-Yuin (see Warner n.d.: 73, 194).

Drawing on the work of Tindale, Flood argued that the archaeological evidence suggests that Katungal Yuin

occupied a series of tribal territories along the coast. In general their country stretches up onto the top of the coastal escarpment, and has the shape of a rectangle or wedge, the shorter side being along the coast. It seems that in the past, as in the present, beach frontage was at a premium. (Flood 1982: 29)

If we return to Howitt's observations, Flood's association of these different subgroups with topographic features and drainage basins has some resonance. Howitt observed that 'when a child was born among the Yuin, its father pointed out some hills, lakes or rivers to the men and women there present as being the bounds of his child's country' (Howitt 1904: 83).

In terms of linguistic differences between Yuin country groups, Eades (1976) and Wesson (2000) have presented somewhat different maps of language distribution. Tindale (1974) also provided a map of tribal and linguistic diversity, though his work makes no distinction between language groups and groups with proper names. Eades' study included the languages Dharawal (Tharawal), Dhurga (Thoorga), Dyirringan (Jeringan) and Thawa (Thauaira) (Eades 1976: 6). Wesson's study differs in the geographical range of these languages and used a comparison of vocabulary lists to determine the relative commonality between the languages (Wesson 2000: 156). A combination of these studies suggests that in the Eurobodalla, the dialects of Jeringan and Thoorga comprised a common language for the Yuin ranging from Wallaga Lake to Batemans Bay, with the

12 The origin of these names were the words katung (meaning 'the sea'), and paien ('a tomahawk'). The groups were known to the colonists as 'fishermen' and 'waddymen', respectively. The word 'waddy' was an Aboriginal word for tree and was used in reference to Paiendra people's proclivity to climb trees as part of the food quest (Howitt 1904: 82). 
Thurumba dialect being spoken north to Conjola Creek. Tharawal, a distinct language, appears to be common from Ulladulla to as far north as Sydney. To the west, the languages of the highlands and plateau were Ngarigo and Ngunawal.

Howitt provides details about Yuin marriage practices and observes that marriage was exogamous both through totemic classification and locality. One of Howitt's informants stated that the rules of marriage were that no one 'should marry so as to mix the same blood, but he must take a woman from a different name (Mura, totem) than his own; and besides this, he must go for a wife to a place as far as possible from his own place' (Howitt 1904: 262). Howitt also describes the arrangement of marriages by respective fathers at the conclusion of the male initiation ceremony, the style of punishment meted out for elopement, and mother-in-law avoidance. Howitt further observed that

many of the old men among the Yuin, especially the principal Gommeras, had more than one wife, and there was one man who had ten, but not at the same time. He was in the habit of giving a wife to some poor fellow who had not any, and thus securing his adherence, and at the same time reducing the number he had to hunt for. (Howitt 1904: 266)

This level of polygyny amongst senior and powerful men reflects Keen's observation that 'since marriage was an exchange, highly polygynous men occupied a key place in exchange networks' (Keen 2004: 179). However, there is little to support Howitt's observations in the census lists, which leads me to believe that high levels of polygyny were anomalous in the nineteenth century and were restricted to the principal Gommeras and, perhaps, a handful of senior men.

The combination of observations and understandings that can be drawn from Mathews' scattered papers (and Elkin's analysis) offers far more complexity than Howitt's description of marriage rules, by describing betrothal based upon relationships. Mathews learnt that the first step was for elders to identify a possible wife's mother who would then give birth to the wife of the male child. As Elkin stated, 'The selection of mother-in-law, rather than of wife, was widespread in Australia, though possibly RHM was the first to say so in specific words' (Elkin 1976: 210). ${ }^{13}$

13 Both Mathews (see Elkin 1976: 211) and Howitt (1904: 266) described the practice of mother-in-law avoidance amongst the Yuin. 
As Elkin noted, Mathews changed his views on Aboriginal social organisation in $1900 .{ }^{14}$ Mathews had previously thought that

all Australian tribes are divided into two exogamous inter-marrying classes, with subdivisions into smaller segments, each having a distinctive title. In cases where these divisions have been believed to be absent, it has probably been rather from their having escaped the notice of investigators than from their non-existence. These class divisions have been called organisations or systems. (Mathews 1894: 18)

Similarly, Howitt observed that 'the class system is in a decadent condition' for the 'Yuin tribes' because 'there are no class names or even traces of them, but very numerous totems scattered over the country, as in the case in the tribes with descent in the female line' (Howitt 1904: 133). According to Mathews' reasoning at the time, any absence of (or unclear delineations between) class divisions could be explained either by poor research or 'that they had formerly existed, but had dropped out of use, leaving traces which the diligent searcher might find' (Elkin 1976: 209). ${ }^{15}$ Following extensive fieldwork at a number of locations during the late 1890s, Mathews found that there was no evidence on the south coast of discrete exogamous intermarrying classes.

Considering himself to be a diligent researcher, Mathews came to the conclusion that it was possible that these class divisions did not exist. Rather, 'marriages were regulated by a system of betrothals, based primarily on relationship' (Elkin 1976: 210). Mathews realised that appropriate marriages were between a man and the daughter of his father's cross-cousin-either the daughter of his father's father's sister's daughter or the daughter of his father's mother's brother's daughter. What Howitt thought was simply 'sister exchange' between two exogamous (but barely recognisable) 'classes' was, according to Mathews, the exchange of the man's sister to the wife's brother; that is, the marriage of the latter with the daughter of his mother's male cross-cousin. ${ }^{16}$ This system of marriage (not organised between exogamous totemic categories, except for the avoidance of marriage between those with the same guardian totem) is congruent with Keen's (2004: 181) analysis of the Kŭnai.

14 Elkin notes that all the 'big names' of the era (Howitt, Fison and Spencer) were influenced by 'Lewis Morgan's theory of the development of marriage from primitive promiscuity, through a phase of group marriage and eventually to individual marriage' which associated class divisions 'with a form of group marriage' (Elkin 1976: 234). Mathews' diversion from this school of thought led to widespread criticism of his work. Elkin clearly believed that Mathews' theories were groundbreaking and that his own analysis of Mathews' material provided vindication.

15 I take this to be a thinly veiled criticism of Howitt.

16 Elkin argues that 'such marriages could not be correlated with exogamous classes and sub-classes (moieties and sections), and if they occurred after the introduction of such divisions, they would be regarded as irregular' (Elkin 1976: 211). 
There is insufficient information in the sources to provide a model of Yuin kinship based on the classification of relatives. Mathews' and Howitt's observations are concordant that Yuin society was not organised around a moiety or section system. The available evidence also suggests that Yuin systems of kin classification do not fit with Kariera-like terminology, which Keen found to 'have been very adaptable, occurring in a range of environments' (Keen 2004: 396). Based on the evidence in hand, we can generalise that Yuin kinship involved extensive networks of relatedness within and between exogamous intermarrying country groups. These marriage rules are consistent with Howitt's observation that totemic classifications were exogamous. ${ }^{17}$ Mathews also observed that 'each tribe is made up of a number of families or groups, each of which has a local position in some part of the tribal country ... In tribes with agnatic descent ... the totems are perpetuated through the man' (Mathews 1894: 21). Patrifilial budjan totems were associated with different places and different country groups or patri-clans that probably reflected some proliferation of the totemic species in that location. Therefore, in a similar manner to what Keen describes in the case of the Kŭnai, 'totemic affiliations both distinguished localities and created connections' (Keen 2004: 279). ${ }^{18}$

Totemic identities were (and are) also incorporated into Yuin cosmology or a general worldview including

non-totemic male and female creator beings, and other non-ordinary beings ... The creator beings made the other beings and the totems ... The spirits of creators such as Tunku and Ngardi have been metamorphosed in the features of sacred sites in the area, just as Umbarra, the black duck, has become the form of the island in the middle of the Lake.

Yuin people's cosmology of creation starts with Darumala (Daruma, or Darumalan), and his mother, Ngalalbal, along with two other creator beings, Tunku and Ngardi. (Rose et al. 2003: 40-1)

17 Through more recent ethnographic research, Deborah Rose is highly critical of Howitt's approach, and argues that 'his work generally does not take women's knowledge or practice into account' (Rose et al. 2003: 40). Rose found evidence that totemic classifications were (and are) bestowed upon children by both men and women (ibid.). While Rose is correct that there is a significant bias towards male knowledge and practice in Howitt's work, the presence of matrilineal totems in the nineteenth century is problematic for Mathews' schema of appropriate marriages. This can be explained in two ways: either matrilineal totems (which were observed neither by Howitt nor Mathews) might have been a separate category that did not affect marriage practices, or the significant disruptions to Yuin social worlds in the late nineteenth and twentieth centuries meant that it was necessary for the conferral of totems to become more flexible according to gender.

18 Mathews believed that this system of social organisation was characteristic of all the 'tribes' of the 'south-eastern coastal district' of NSW (see Mathews and Everitt 1900: 262-3). 
The activities of these creator beings are mapped onto the landscape as Dreaming stories and tracks. As Rose notes, "The term "Dreaming" covers a range of interconnected concepts including Dreaming ancestors and their creative journeys, religious laws, sacred designs and songs, and codes of social order' (ibid.: 21-2).

The nature of Yuin male initiation is the only reference Howitt gives to ceremonial practices in the study region. Yuin youths were given cicatrices after the initiation ceremonies and, as Howitt observed, 'scars are cut on both boys and girls' (Howitt 1904: 746). There is no evidence that Yuin people practised circumcision or subincision, however tooth avulsion was part of the male initiation ceremony. The ceremonies were coordinated by the principal Gommera of the officiating 'tribe'. According to Howitt, Gommeras were the headmen of the local divisions and 'must be a medicine-man, must be aged, able to speak several languages (dialects), be skilful as a fighting-man, and be, above all, able to perform those feats of magic which the Gommeras exhibit at the initiation ceremonies' (Howitt 1904: 314). While governance within these local divisions largely rested on the will of the powerful Gommeras, Howitt also observed what he called 'tribal councils' that included all the initiated men to discuss particular problems. Howitt was 'struck by the restrained manner of the younger men at these meetings' (Howitt 1904: 325). This 'restraint' reflected the norms of respect and ancestral laws that were impressed upon initiates during the ceremony.

\section{Economy}

Under the broader heading of economy, Keen (2004: 275) examines 'resources, relations, and practices according to economic categories'. Accordingly, this section examines the way in which country groups accessed resources and controlled the means of production through use-rights, the organisation of production through gendered divisions of labour, the organisation of distribution and consumption, and exchange and trade.

Howitt observed that male children were given rights to their father's country and to the country of their birth. However, he also wrote (1904: 83) that the Yuin observed a range of use-rights to country, including man's place of birth, a man's father's place of birth, a father's sons' place of birth, a woman's place of birth, a woman's mother's place of birth, and a mother's daughters' place of birth. In addition to use-rights associated with the place of one's birth or parents' place of birth, use-rights were also governed by totemic classifications. Oral history documents 'the restrictive Aboriginal lores governing access to traditional ecological knowledge, including that relating to the location, 
distribution, collection and preparation method of flora used for food and medicines' (Dale Donaldson 2006: 13). Prior to colonisation, these restricted knowledges probably governed use-rights for particular resources. ${ }^{19}$ Therefore, Aboriginal people in the Eurobodalla benefited from a mix of rights in a number of different countries. ${ }^{20}$

In terms of the division of labour, Bowdler argues that the procurement of food was 'according to technique. Men invariably used the four-pronged bonebarbed spear; women fished with a hook and line, using a shell hook and a vegetable fibre line' (Bowdler 1976: 254). Bowdler further remarks:

Woman doubtless spent a good deal of their time gathering shellfish; and this was probably done in a thorough and systematic fashion, with due regard to the schedules imposed by the tides ... While spears were sacrosanct to men, the new implement, the shell hook which appeared some 600 years ago, had no such status adhering to it. (Bowdler 1976: 256)

Lampert's research supports this view and argues that Yuin people were organised around a 'strict sexual division of labour in using this equipment: women always fished with hook and line, men with spears' (Lampert 1971: 118).

Unfortunately, Howitt did not provide information on the composition of residence groups and patterns of distribution and consumption on the south coast. Warner's papers provide more helpful (if limited) details relating to the Brinja-Yuin, for whom the economic unit was observed to be a family group living at one wurley (Warner n.d.: 73). Warner thought that the Brinja-Yuin were organised around a 'semi-nomadic' lifestyle centred on 'semi-permanent' campsites that provided a base for food gathering expeditions (Warner n.d.: 94). Warner's papers suggest that during times of abundance, residence groups were considerably larger and gendered 'work teams' exploited coastal resources collectively. The ecological and archaeological evidence suggests that women and men generally worked and hunted separately, with women collecting shellfish and fishing with hooks and line during the day. It appears that much of the fishing men did was during the evening when fish could be startled using a torch and then speared, while during the day men sometimes hunted terrestrial game (including macropods).

Drawing on archaeological and ethnographic evidence and comparative material, Bowdler argues that 'fish - like other meat — was monopolised by men, despite the contribution of female effort in making the catch' (Bowdler 1976: 256). Bowdler postulates that Aboriginal men and women had different diets, with

19 Not only did totemic classifications denote use-rights for individuals and groups, but they also entailed responsibility for 'holding' that country by protecting and nurturing it.

20 This is consistent with Keen's (2004) comparison of seven different regions. 
men consuming the lion's share of scale fish and any mammals that were caught, while women subsisted mainly on shellfish. ${ }^{21}$ From a comparative perspective, this picture of distribution and consumption is overly simplistic. As Keen notes for Aboriginal economies in general, 'certain kinds of relationships required particular kinds of gifts' (Keen 2004: 337). While the evidence doesn't exist in the record, it is likely that the produce from both men's and women's labour were distributed according to particular kinds of kin obligations. Furthermore, distribution amongst Yuin people probably also followed patterns of what Peterson calls 'inertial generosity' in which people simply 'respond to demands as they are made' (Peterson 1993: 864). ${ }^{22}$ However, as Keen further suggests, 'degrees of familiarity and constraint entailed by different kin relationships also affected the ability to make demands' (Keen 2004: 337).

Howitt's observations illustrate that a range of restrictions were placed on male initiates relating to consumption prohibitions during the seclusion phase of their initiation. Following the removal of the tooth, the Gumbang-ira ('rawtooth novice') was prohibited from eating emu, any animal which burrows in the ground (e.g. wombat), creatures that have prominent teeth (e.g. kangaroo), any animal that climbs to the treetops (e.g. koala), any bird that swims, echidna, possum, lace-lizard, snakes, eels and perch, and the budjan (totem) of the novice. Howitt noted: 'Thus the young man during his probation is placed in an artificial state of scarcity as to food, although perhaps surrounded by plenty' (Howitt 1904: 560). ${ }^{23}$ Most of these food prohibitions related to cosmology and processes undertaken during the ceremony. ${ }^{24}$

While various consumable items were distributed within Yuin residence groups, durable objects were exchanged with other groups based on regional specialisations. It appears that the Kuringal gathering also served as an opportunity for trade. Howitt writes, 'At the termination of the initiation ceremonies, at which the whole intermarrying community were present, a meeting was held near the camp at which things were bartered' (Howitt 1904: 263). Howitt (ibid.: 718-20) provides a valuable level of detail regarding these exchange practices, in which durable goods (alienable possessions) were

\footnotetext{
21 This argument hinges on evidence that shellfish remnants are broadly spread over a number of sites, leading Bowdler to believe that much of an Aboriginal woman's 'food is consumed while gathering away from the camp' (Bowdler 1976: 252).

22 Peterson's model of 'demand sharing' addresses the problem of negative reciprocity (or 'freeloading') (Peterson 1993: 860).

23 Howitt thought that these restrictions were removed when the Gommeras had deemed the novices fit to return to their groups. However, Mathews suggests that food prohibitions were incrementally lifted when men had attended a certain number of initiation ceremonies, although he doesn't state explicitly how many (Mathews 1896).

24 For example, the emu was prohibited because it was Ngalalbal (the mother of Darumalan the creation being), while kangaroos (and other animals with prominent teeth) were thought to remind the Gumbang-ira of the missing tooth.
} 
exchanged and relationships were reaffirmed through gifts to important or powerful leaders (inalienable gifts). Similarly, ceremonial and auspicious items were exchanged along what appears to be a much broader trading network.

\section{Conclusion}

This chapter has provided the first systematic profiling of Yuin economy and society within the Eurobodalla region of the New South Wales south coast at the threshold of colonisation. It has demonstrated the usefulness of Keen's approach of using the comparable and relatively reconstructable categories of ecology, institutional fields and economy to shed light on the character of this region, and has paid homage to Keen's invaluable contribution to economic anthropology, and to a comparative understanding of the variation in Aboriginal economies and societies across Australia.

In view of the ethnographic, archaeological and linguistic evidence, Yuin (as an identity) existed as a conglomerate of intermarrying country groups sharing a coastal/escarpment orientation, mutually intelligible language and who participated in common ceremonial activities. In the Eurobodalla, these country groups had their own range, and individual rights to country were determined by a variety of claims. The conclusions for this chapter are presented in Table 12.1, borrowing from Keen's comparable categories within Aboriginal economies and societies. Sadly, the available evidence for the Eurobodalla region is inadequate to comprehensibly profile the full extent of Yuin institutions and economy, particularly in relation to kinship terminology, cosmology and patterns of distribution.

The profile of the Yuin in this chapter is broadly consistent with Keen's profiling of the Kŭnai, with a great deal of similarity in the ecology, economy and institutions of each group, and a degree of intermarriage, and mutual involvement in shared ceremonial practices and trade, between the two groups. ${ }^{25}$ Keen refers to the Kŭnai as occupying part of a broad resource zone in the southeast, rather than as exemplifying economic or social characteristics shared by people in that region (Keen 2004: 382-3). Both the Kŭnai and the Yuin populated an area with a vast array of similar lacustrine, estuarine and coastal resources and developed similar technologies to utilise those resources (including nets, fish hooks, spears

\footnotetext{
25 Both Mathews and Howitt observed the presence of Kŭnai people at Yuin ceremonies, which included exchange and trade. The genealogical records I was able to compile during my $\mathrm{PhD}$ research detail a number of marriages between Kŭnai and Yuin people in the $1800 \mathrm{~s}$ - a pattern that may have predated European incursions into the region. While the information on Yuin marriage practices is incomplete, Howitt observed that the Yuin, like the Kŭnai, discouraged marriage between geographically close people, and close relatives - a practice that probably encouraged marriage between the two groups.
} 
and canoes). The Kŭnai and Yuin had similar population densities and range of seasonal movements, as well as similarly comprised country groups holding a range of use-rights to various estates. In both these cases, totemic affiliations distinguished localities and created connections for Kŭnai and Yuin people. Further, Yuin creation stories have a similar celestial emphasis to those of the Kŭnai, telling of the creator-ancestors, Tunku and Ngardi, coming down from a star to inhabit the earth. Howitt also documented Yuin ancestral stories involving the Milky Way (Howitt 1904: 664), where the spirits of the dead inhabited the sky. This evidence is consistent with Keen's assertion of a celestial emphasis in the cosmology of the southeast region, as opposed to the strong terrestrial emphasis in the Western Desert (Keen 2004: 387).

\section{Table 12.1 Key features of Yuin economy and society in the Eurobodalla in the late eighteenth century.}

\begin{tabular}{|c|c|}
\hline Environment & $\begin{array}{l}\text { Estuarine systems, intertidal zones, marine habitats, drainage } \\
\text { basins, plains, temperate forests. }\end{array}$ \\
\hline Resources & $\begin{array}{l}\text { Mainly coastal and riverine resources, food plants (fruits, roots, } \\
\text { rhizomes and tubers), birds, reptiles and mammals. }\end{array}$ \\
\hline Population density & $\begin{array}{l}\text { Keen's estimates for the Kŭnai seem to be a reasonable } \\
\text { comparison based on similar environments and resources. } \\
\text { Population densities may have been as high as one person per } \\
\text { square kilometre around the estuaries. In the foothills population } \\
\text { densities may have been medium to high (one person per 6-12 } \\
\text { square kilometres) and considerably lower in the upper escarpment } \\
\text { (see Keen 2004: 107). }\end{array}$ \\
\hline Technologies & $\begin{array}{l}\text { Canoes and rafts, fishing spears with variable tips, torches for } \\
\text { startling fish at night, bone or shell fishing hooks, fishing lines, fish } \\
\text { traps, possum cloaks/rugs, wurleys, an assortment of clubs, axes, } \\
\text { spears and boomerangs. }\end{array}$ \\
\hline Seasonal patterns & Generally aseasonal but some movement inland during winter. \\
\hline $\begin{array}{l}\text { Language and regional } \\
\text { identities }\end{array}$ & $\begin{array}{l}\text { Three dialects and possibly four regional identities within the } \\
\text { Eurobodalla (Kurial/north, Guyangal/south, Katungal/east, } \\
\text { Paiendra/west). }\end{array}$ \\
\hline Local identities & $\begin{array}{l}\text { Based on countries with totemic significance. Countries associated } \\
\text { with geographical features and/or drainage basins. Coastal } \\
\text { 'estates' with narrow beach frontages. }\end{array}$ \\
\hline Totemic identities & $\begin{array}{l}\text { Patrifilial budjan totems, country-groups identified by locality. } \\
\text { Strong correlation between patrifilial totems and totemic } \\
\text { significance of country. }\end{array}$ \\
\hline Kinship terminology & $\begin{array}{l}\text { Insufficient information in sources. Evidence suggests an extensive } \\
\text { network of relatedness with no moiety system. }\end{array}$ \\
\hline Level of polygyny & $\begin{array}{l}\text { Possibly high. The evidence suggests that some senior or powerful } \\
\text { men were highly polygamous (see Keen } 2004 \text { : 178-9, 206-7). }\end{array}$ \\
\hline Governance & $\begin{array}{l}\text { Gommeras (headmen) acted as local bosses, magicians, ritual } \\
\text { leaders and healers. }\end{array}$ \\
\hline Cosmology & Strong celestial emphasis. \\
\hline
\end{tabular}




\begin{tabular}{|l|l|}
\hline Use rights & $\begin{array}{l}\text { Country of birth, father's country, mother's country, country of } \\
\text { child's birth, country associated with totemic identity. }\end{array}$ \\
\hline Organisation of production & $\begin{array}{l}\text { Highly gendered by resource and technologies associated with } \\
\text { those resources. }\end{array}$ \\
\hline Distribution and consumption & $\begin{array}{l}\text { Insufficient information in sources. Comparative material suggests } \\
\text { generalised reciprocity, demand sharing and kin obligations shaped } \\
\text { distribution. Totemic and ceremonial restrictions on consumption. }\end{array}$ \\
\hline Exchange and trade & $\begin{array}{l}\text { Exchange and trade of alienable possessions and inalienable gifts } \\
\text { during ceremonial gatherings. }\end{array}$ \\
\hline
\end{tabular}

Given the strong similarities between the Yuin material and Keen's profile of the Kŭnai, it is tempting to conclude that the Yuin and Kŭnai occupied a broad 'south-east zone' of shared economic and social characteristics, although more work on uncovering and understanding information about Yuin institutions (particularly kinship terminology) would be necessary. Further research of this type in the southeast of the Australian continent could establish whether such a zone was spread more broadly, further adding to the nuances of similarity and difference in Aboriginal ecology, economy and society that Keen has so compelling presented.

Keen concludes his 2004 monograph by suggesting that the character of Aboriginal economy and society in a particular region may have assisted in shaping the course of intercultural relations on the frontier and beyond, whereby 'certain forms of social organisation and leadership made stronger resistance possible in some areas, or made it possible for Europeans and others to become incorporated into Aboriginal exchange systems' (Keen 2004: 398). In doing so, Keen foreshadows a productive dialogue between the theoretical and methodological approaches of anthropology and history, an exchange of ideas that was developed by contributors to the two edited volumes of Indigenous Participation in Australian Economies (Keen 2010; Fijn et al. 2012), documenting the nature and variety of Aboriginal and Torres Strait Islander engagements with the settler economy from the colonial era to the present day. Further research of this type will assist in developing anthropological analyses of Aboriginal and Torres Strait Islander economic relations, and the articulation of Indigenous economies with market capitalism and the state.

\section{References}

Altman, J. 1987. Hunter-Gatherers Today: An Aboriginal Economy in North Australia. Canberra: Australian Institute of Aboriginal Studies.

Anderson, C. 1984. The Political and Economic Basis of Kuku-Yalinji Social History. PhD Thesis, University of Queensland, Brisbane. 
Attenbrow, V. 1999. Archaeological research in coastal southeastern Australia: a review. In J Hall and I. McNiven (eds), Australian Coastal Archaeology, pp. 195-210. Canberra: The Australian National University.

Bourdieu, P. 1977. An Outline of a Theory of Practice. Cambridge: Cambridge University Press.

Bowdler, S. 1976. Hook, line and dilly bag: an interpretation of an Australian coastal shell midden. Mankind 10(4): 248-58.

Butlin, N. 1985. Macassans and aboriginal smallpox: the '1789' and '1829' epidemics. Australian Historical Studies 21: 315-35.

Butlin, N. 1993. Economics and the Dreamtime: A Hypothetical History. Melbourne and Cambridge: Cambridge University Press.

Campbell, J. 2007. Invisible Invaders: Smallpox and Other Diseases in Aboriginal Australia, 1780-1880. Carlton, Vic.: Melbourne University Press.

Chittick, L. 1992-93. Interviews-Percy Mumbulla Project Canberra, Recorded Sound Archive, AIATSIS.

Chittick, L. and T. Fox. 1997. Travelling with Percy: A South Coast Journey. Canberra: Aboriginal Studies Press.

Correy, S., D. McCarthy and A. Redmond. 2008. The differences which resemble: the effects of the 'Narcissism of Minor Differences' in the constitution and maintenance of native title claimant groups in Australia. Australian Anthropological Society Annual Conference. Auckland, NZ.

Dale Donaldson, S. 2006. Stories about the Eurobodalla by Aboriginal People. Eurobodalla Aboriginal Cultural Heritage Study. Stage Two. Moruya, NSW: Susan Dale Donaldson Environmental and Cultural Services.

Dale Donaldson, S. 2008. Aboriginal Men and Women's Heritage: Eurobodalla. Moruya, NSW: Eurobodalla Shire Council.

Dingle, A.E. 1988. Aboriginal Economy: Patterns of Experience. Melbourne: McPhee Gribble.

Eades, D. 1976. The Dharawal and Dhurga Languages of the New South Wales South Coast. Canberra: Australian Institute of Aboriginal Studies.

Elkin, A.P. 1975a. R.H. Mathews: his contribution to Aboriginal studies. Part one. Oceania 46: 1-24.

Elkin, A.P. 1975b. R.H. Mathews: his contribution to Aboriginal studies. Part two. Oceania 46: 126-52. 
Elkin, A.P. 1976. R.H. Mathews: his contribution to Aboriginal studies. Part three. Oceania 46: 206-34.

Fijn, N., I. Keen, C. Lloyd and M. Pickering (eds). 2012. Indigenous Participation in Australian Economies II: Historical Engagements and Current Enterprises. Canberra: ANU E Press.

Flood, J. 1980. The Moth Hunters: Aboriginal Prehistory of the Australian Alps. Canberra: Australian Institute of Aboriginal Studies.

Flood, J. 1982. Katungal, Paindra and Bemeringal. In S. Bowdler (ed.), Coastal Archaeology in Eastern Australia: Proceedings of the 1980 Valla Conference on Australian Prehistory, pp. 29-31. Canberra: Australian National University Press.

Giddens, A. 1979. Central Problems in Social Theory: Action, Structure and Contradiction in Social Analysis. London: Macmillan.

Godelier, M. 1999. The Enigma of the Gift. Chicago: University of Chicago Press.

Gregory, C. 1982. Gifts and Commodities. London: Academic Press.

Hiatt, L.R. 2006. Arguments About Aborigines: Australia and the Evolution of Social Anthropology. Cambridge: Cambridge University Press.

Hotchin, K. 1990. Environmental and Cultural Change in the Gippsland Lakes Region, Victoria, Australia. PhD Thesis, The Australian National University, Canberra.

Howitt, A.W. 1904. The Native Tribes of South-East Australia. London: Macmillan.

Howitt, A.W. 1907a. Howitt to Hockey. 13 December 1907. R.H. Mathews Papers. Canberra: National Library of Australia.

Howitt, A.W. 1907b. Howitt to Hockey. 16 September 1907. R.H. Mathews Papers. Canberra: National Library of Australia.

Howitt, A.W. n.d. Papers 1049/3b, 1050/2a, 1050/2c, 1050/4d, 1053/3a, 1053/3b, 1053/4a, 1053/5b, 1054/2a, 1054/2c. Melbourne: State Library of Victoria and Museum of Victoria.

Keen, I. 1993. Ubiquitous ubiety of dubious uniformity. The Australian Journal of Anthropology 4(2): 96-110.

Keen, I. 2000. The anthropologist as geologist: Howitt in colonial Gippsland. The Australian Journal of Anthropology 11: 78-98. 
Keen, I. 2004. Aboriginal Economy and Society: Australia at the Threshold of Colonisation. South Melbourne, Vic.: Oxford University Press.

Keen, I. (ed.) 2010. Indigenous Participation in Australian Economies: Historical and Anthropological Perspectives. Canberra: ANU E Press.

Lampert, R. 1971. Coastal Aborigines of south east Australia. In D.J. Mulvaney (ed.), Aboriginal Man and Environment in Australia, pp. 114-32. Canberra: Australian National University Press.

Lawrence, R.J. 1968. Aboriginal Habitat and Economy. MA Thesis, The Australian National University, Canberra.

Mathews, R.H. 1894. The Kamilaroi class system of the Australian Aborigines. Proceedings and Transactions of the Queensland Branch of the Royal Geographical Society of Australasia 10: 18-34.

Mathews, R.H. 1896. The Bunan ceremony of New South Wales. American Anthropologist 9: 327-44.

Mathews, R.H. 1902. The Thoorga (and Yoolumbill) languages. Queensland Geographical Journal 17: 49-73.

Mathews, R.H. 1904. Ethnological notes on the Aboriginal tribes of New South Wales and Victoria. Journal of the Royal Society of New South Wales 38: 203-381.

Mathews, R.H. and M.M. Everitt. 1900. The organisation, language and initiation ceremonies of the Aborigines of the south-east coast of New South Wales. Journal of the Royal Historical Society of New South Wales 34: 262-80.

Matthews, J. 1965. Language elicitation, local and family histories, and material culture. Canberra: Recorded Sound Archive, AIATSIS.

Mathews, J. 1967. Vocabulary, songs and cultural discussions from south-east Australia. Canberra: Recorded Sound Archive, AIATSIS.

Mauss, M. 1954. The Gift: Forms and Functions of Exchange in Archaic Societies. Glencoe, IL: The Free Press.

Peterson, N. 1993. Demand sharing: reciprocity and the pressure for generosity among foragers. American Anthropologist 95(4): 860-74.

Poiner, G. 1976. The process of the year among Aborigines of the central and south coasts of New South Wales. Archaeology and Physical Anthropology in Oceania 11: 186-200. 
Robinson, G.A. 1844a. Field journals, 13 April-11 May 1844. Unpublished transcription by I.D. Clark (1998). Sydney: Mitchell Library.

Rose, D.B., D. James and C. Watson. 2003. Indigenous Kinship with the Natural World in New South Wales. Hurstville, NSW: NSW National Parks and Wildlife Service.

Rowley, C.D. 1970. The Destruction of Aboriginal Society. Aborigines in Australian Society 4. Canberra: Australian National University Press.

Rowley, C.D. 1971. Outcasts in White Australia. Aborigines in Australian Society 6. Canberra: Australian National University Press.

Sahlins, M. 1974. Stone Age Economics. London: Tavistock.

Spencer, B. and F. Gillen. 1899. The Native Tribes of Central Australia. London: Macmillan and Co.

Swain, T. 1993. A Place for Strangers: Towards a History of Australian Aboriginal Being. Cambridge: Cambridge University Press.

Tindale, N.B. 1974. Aboriginal Tribes of Australia. Berkeley: University of California Press.

Thomas, M. 2004. R.H. Mathews and anthropological warfare: on writing the biography of a self-contained man. Aboriginal History 28: 1-32.

Thomas, M. 2006. A Very Human Survey. Public History Review 12: 12-26.

Thomas, M. 2011. The Many Worlds of R.H. Mathews: In Search of an Australian Anthropologist. Crows Nest, NSW: Allen and Unwin.

Van Gennep, A. 1909. Van Gennep to Mathews. 16 November 1909. R.H. Mathews Papers Canberra, National Library of Australia.

Veth, P. 2006. Review of Aboriginal Economy and Society Economy and Society: Australia at the Threshold of Colonisation by Ian Keen. Australian Archaeology 63: 68-9.

Warner, H. n.d. Ethnography summary of the late Brinja-Yuin tribe of Tuross, N.S.W. Closed Stack. Canberra, AIATSIS.

Weiner, A. 1992. Inalienable Possessions: The Paradox of Keeping-While-Giving. Berkeley: University of California Press.

Wesson, S. 2000. An Historical Atlas of the Aborigines of Eastern Victoria and Far South-Eastern New South Wales. Melbourne: School of Geography and Environmental Science, Monash University. 
Wesson, S. 2002. The Aborigines of Eastern Victoria and Far South-eastern New South Wales, 1830 to 1910: An Historical Geography. PhD Thesis, Monash University, Melbourne.

White, J.M. 2010a. Peas, beans and river banks: seasonal picking and dependence in the Tuross Valley. In I. Keen (ed.), Indigenous Participation in Australian Economies: Historical and Anthropological Perspectives, pp. 109-26. Canberra: ANU E Press.

White, J.M. 2010b. On the Road to Nerrigundah: An Historical Anthropology of Indigenous-Settler Relations in the Eurobodalla Region of New South Wales. PhD Thesis, The Australian National University, Canberra.

White, J.M. 2011. Histories of indigenous-settler relations: reflections on internal colonialism and the hybrid economy. Australian Aboriginal Studies 1: 81-96.

White, J.M. 2012. Before the mission station: from first encounters to the incorporation of settlers into indigenous relations of obligation. In N. Fijn, I. Keen, C. Lloyd, and M. Pickering (eds), Indigenous Participation in Australian Economies II: Historical Engagements and Current Enterprises, pp. 37-56. Canberra: ANU E Press. 
This text is taken from Strings of Connectedness: Essays in Honour of Ian Keen, edited by Peter Toner, published 2015 by ANU Press, The Australian National University, Canberra, Australia. 